\title{
Hydrosedimentological disequilibrium in a small, urbanized watershed
}

Desequilíbrio hidrossedimentológico numa microbacia urbanizada e de pequeno porte

Alexandre Marco da Silva ${ }^{1}$, Alexandre Ribas dos Santos ${ }^{1}$, Rodolpho Augusto Fernandes ${ }^{1}$,

Rodrigo Custódio Urban ${ }^{1}$, Romulo Martins Carvalho ${ }^{1}$,

Luiz Augusto Manfré ${ }^{1}$ and Steven Frederick Durrant ${ }^{2}$

${ }^{1}$ Núcleo de Automação e Tecnologias Limpas, Universidade Estadual Paulista - UNESP,

Campus Sorocaba, CEP 18087-180, Sorocaba, SP, Brazil

e-mail:amsilva@sorocaba.unesp.br; alexandresantos_unesp@yahoo.com.br; rodolphoff@hotmail.com;

rourban@gmail.com; romulomcarvalho@gmail.com; luizmanfre@gmail.com

${ }^{2}$ Grupo de Plasmas e Materiais, Universidade Estadual Paulista - UNESP, Campus Sorocaba,

CEP 18087-180, Sorocaba, SP, Brazil

e-mail: steve@sorocaba.unesp.br

\begin{abstract}
Aim: In this paper we estimate the sediment yield and other related information for a small urbanized watershed, located in Sorocaba, São Paulo State. The driving forces that produce the observed scenario are presented and discussed; Methods: Over a year, water samples and hydrologic information concerning the river channel were collected monthly at one sampling site. In the laboratory, water samples were oven dried $\left(80^{\circ} \mathrm{C}\right)$ and the total suspended solid weighed for each sample. To estimate sediment yield we used Colby's simplified method. The sediment delivery ratio (SDR) was estimated using two methods: the relief - length ratio and the bifurcation ratio; Results: The annual sediment yield estimated for the period was 1,636.1 t. The total specific sediment yield was $541.7 \mathrm{t} \cdot \mathrm{km}^{-2} \cdot \mathrm{y}^{-1}$. Bedload was the predominant fraction. The SDR changed between 60 and 66\% according to the method employed. Conclusions: The main driving forces of hydrosedimentological disequilibrium are the lack of riparian vegetation, the dumping of construction wastes at inadequate sites, and the launching of untreated sewage. Hence, if these three factors were controlled, a significant improvement in the environmental quality, particularly water quality, might be achieved.
\end{abstract}

Keywords: hydrosedimentology, Colby's simplified method, sediment yield, environmental impact.

Resumo: Objetivo: Neste trabalho nós estimamos a produçáo de sedimentos para uma microbacia urbanizada e de pequeno porte, localizada em Sorocaba, Estado de São Paulo. Discutimos as principais causas que levaram ao cenário observado; Métodos: Durante um ano, amostras de água e informaçóes hidrológicas sobre o canal do rio foram coletadas num ponto de amostragem. Em laboratório, amostras foram secas em estufa $\left(80^{\circ} \mathrm{C}\right)$ e o total de sólido suspenso foi pesado para cada amostra. Para a estimativa da produção de sedimentos nós usamos o método simplificado de Colby. A Razão de Transferência de Sedimentos (RTS) foi estimada por dois métodos: a razão relevo - comprimento e a razão de bifurcação. Resultados: a produção anual de sedimento estimada para o período foi 1.636,1 toneladas. A produção específica de sedimentos foi $541.7 \mathrm{t} \cdot \mathrm{km}^{-} 2 \cdot \mathrm{ano}^{-1}$. A carga de arraste foi a fraçáo predominantemente produzida. RTS variou entre 60 e $66 \%$ de acordo com o método empregado. Conclusôes: As principais forças que causam o desequilíbrio hidrossedimentológico são a falta de vegetação ciliar, o despejo de resíduos de construçáo civil em locais inadequados e o lançamento de esgoto náo tratado. Portanto, se os três principais fatores fossem controlados, uma melhoria significativa na qualidade ambiental seriam obtidos, principalmente em relaçáo à qualidade da água.

Palavras-chave: hidrossedimentologia, método simplificado de Colby, produção de sedimentos, impacto ambiental. 


\section{Introduction}

Urban areas are characterized by a greatly modified physical, chemical and biological environment, resulting from the construction of buildings on a large spatial scale (Taylor and Owens, 2009). Urbanization involves the growth of construction sites, which normally generate construction wastes, among them construction-related sediment (Chin, 2006). Owing to urbanization, there are also changes in the regimes of runoff and soil loss rates, which also affect the dynamics of the hydrosedimentological site.

The initial phase of urban development is characterized by a two to ten fold increase in sediment mobilization, usually caused by disruptions to the watershed, which results in deposition in the channels (Martin, 2011).

Solid waste generated at construction sites, and disposed of incorrectly, may represent an important source of sediment banks found along stretches of the river network (Ooshaksaraie et al., 2009). Some construction wastes, such as sandy materials, can be transported to water courses and dispersed in the watershed as suspended load or bedload. Increases in the concentration of coarse sand and decrease in gravel fractions have been observed in urban rivers as a result of changes in sediment yield and in the velocity of waterway (Paul and Meyer, 2001).

Many studies have demonstrated that upland land use can influence riverine ecosystems (Gergel et al., 2002). Changes in hydrological features, combined with the supplementary input of sediment from construction and also modifications in the river channel, result in geomorphological changes in stream systems (EPA, 2009). The major impact of urbanization on basin morphometry is a modification of drainage density (i.e. a decrease in sinuosity) (Paul and Meyer, 2001).

A range of other changes have also been documented. These include increases in bed material size and in drainage density, along with other chemical, biological, and ecological effects. Some of these changes may be transient, such as the increase in sediment production and sediment loads, which are part of the river landscape only until they are flushed away. But others are more lasting, especially channel enlargement or incision. In this regard, urban development does leave permanent imprints on river landscapes (Chin, 2006).

For urbanized watersheds, it is difficult to predict mathematically the sediment yield, especially if the urbanization process is spontaneous or unplanned. For small, urbanized watersheds located in subtropical regions of the Southern Hemisphere, few studies have been conducted and published regarding this theme (Scapin et al., 2007; Souza et al., 2009). The database generated in such studies may be useful to develop or improve strategies of land use and for the recuperation of degraded areas.

In South American cities, urban expansion usually occurs in a disorganized way and is not accompanied by adequate supporting infrastructure, leading to negative impacts on the environment (Poleto et al., 2009). Consequently, on this continent, there are few unpolluted streams or rivers in urban areas. Especially for Sáo Paulo State, the most populated State in Brazil, the water quality is deteriorating (Groppo et al., 2008). Furthermore, for many countries, including Brazil, untreated sewage is still launched illegally into streams (Araujo et al., 2008), and may contribute to the sediment imbalance of the watershed, in both particulate and dissolved forms.

The observation of the effect of changes in land use on sediment mobilization in a small catchment area is an essential first step in a strategy to comprehend the problems, stress the driving forces, and collaborate on a solution of the associated problems (Porto et al., 2009). Studies addressing the hydrosedimentological dynamic should be encouraged in these regions. Hence, the aim of this paper is to estimate the sediment yield for a small, urbanized watershed and discuss the driving forces.

\section{Material and Methods}

\subsection{Study area}

Sorocaba is located in the countryside of São Paulo State. It is roughly $100 \mathrm{~km}$ from the capital city, São Paulo (Figure 1). It has an area of $449 \mathrm{~km}^{2}$ and about 550,000 inhabitants. The Lavapés watershed falls within the boundary of Sorocaba city. The catchment area is $3.02 \mathrm{~km}^{2}$.

In the study area the average annual rainfall is $1,285 \mathrm{~mm}$. Predominant soil classes are Oxisols and Ultisols (Oliveira et al., 1999). Altitude ranges from 545 to $653 \mathrm{~m}$ and the relief is predominantly plane (average slope 5\%) (Silva, 2007).

Urban settlement is the major land cover category $(71.5 \%)$ in the study area. Some areas with anthropized pastures also occur (9.6\%). Natural remnant vegetation occurs in approximately $11 \%$ of the area and almost all streams have no forested riparian strips. Eight remnant forest patches (practically not riparian), of different sizes, still exist 
in the area (Figure 2) (Silva et al., 2011). The major part of the settlement is residential, of various social classes. Urban settlements usually reach the water courses. One consequence of this is the launching of untreated domestic sewage at many sites along the river network. There are few public, tree-lined gardens. There is little commerce and few industrial establishments. There are a few small country houses and without livestock.

\subsection{Procedures}

Sediment yield was estimated using Colby's simplified method (Carvalho, 1994; Vanoni, 2006; Silva and Schulz, 2007) (Equations 1, 2, 3):
Qst $=$ Qsm + Qnm

$\mathrm{Qsm}=0.0864 \times \mathrm{Q} \times \mathrm{C}$ 's

Qnm $=$ q'nm $\times \mathrm{K} \times \mathrm{L}$

Where: Qst total sediment yield, in $\mathrm{t} \mathrm{day}^{-1}$, Qsm - quantified solid discharge, in $\mathrm{t} \mathrm{day}^{-1}$, Qnm - non quantified solid discharge, in $\mathrm{t} \mathrm{day}^{-1}$, $\mathrm{Q}$ - stream discharge, in $\mathrm{m}^{3} \mathrm{~s}^{-1}$, C's - quantified concentration of sediment, in parts per million (ppm), L - channel width, in m, q'nm - not quantified solid discharge (estimated according to the width of the drainage channel), $\mathrm{K}$ - correction factor.

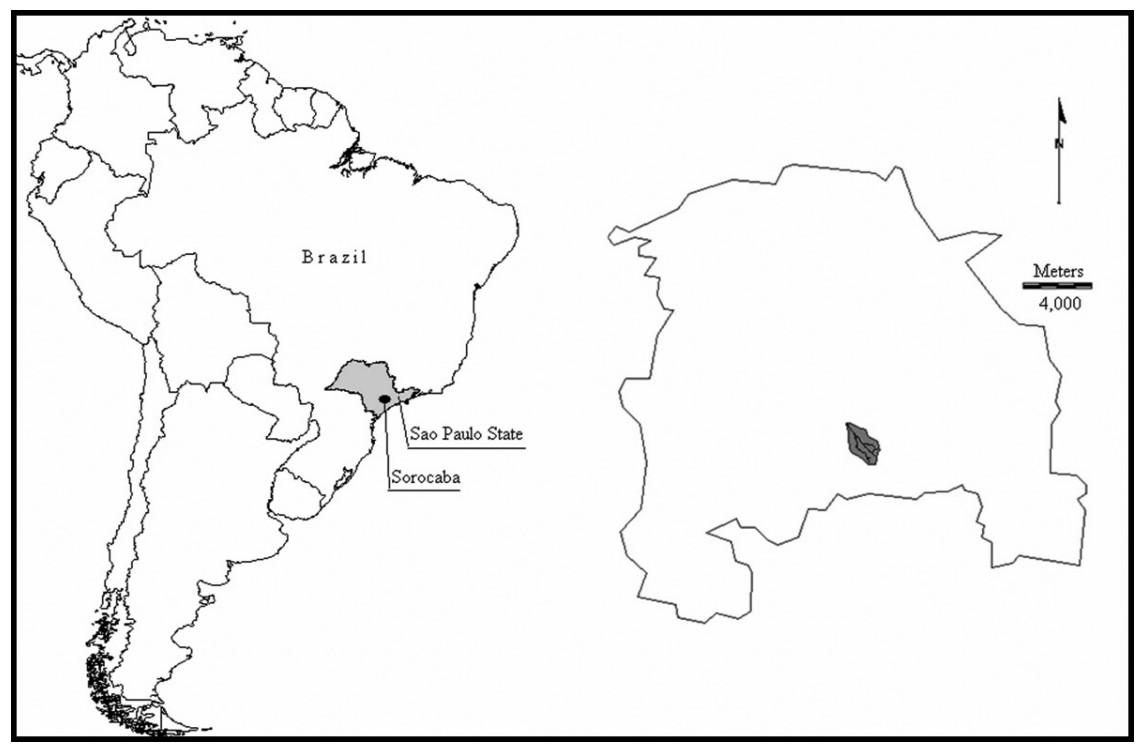

Figure 1. Left: Location of Sorocaba City in São Paulo State (Source: Silva, 2007). Right: Location of the watershed in Sorocaba City.

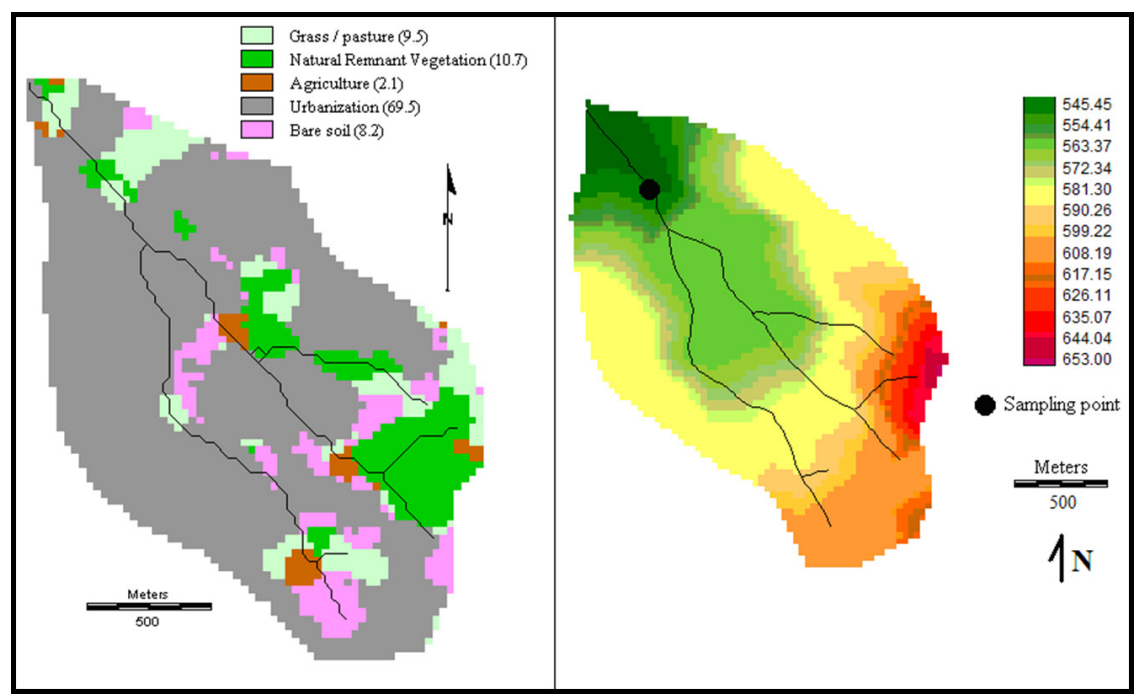

Figure 2. Left: Land cover map with the percentages of each land cover class. Right: Digital Elevation Model of the study area. Source Urban (2011). 
The $\mathrm{Q}_{\mathrm{NM}}$ and $\mathrm{K}$ components were estimated using three algorithms that require information regarding flow velocity, average channel depth and sediment concentration (Carvalho, 1994; Vanoni, 2006). Use of Colby's method requires knowledge of the average channel depth, sediment concentration, average flow velocity and channel width. Such information was obtained monthly over one year in a trapezoidal, low slope, concrete surfaced and opened river channel.

The cross-section (the water depth from bank to bank) was determined at the same point used for water sampling, through a bathymetric profile. The area of the channel and the average depth were computed.

The float method (USDI, 2001) was used to determine the waterway's velocity. A float was launched from one pre-determined point upstream. When the float crossed a determined point upstream, a chronometer was started. When the float crossed a determined point $10 \mathrm{~m}$ downstream, the chronometer was stopped and the time recorded. This operation was executed ten times on each sampling date, always using the same upstream and downstream points. The average time was determined by computing the arithmetic average of the ten recorded values, and the average flow velocity was calculated by division of the distance $(10 \mathrm{~m})$ by the average time.

For the total suspended solids (TSS) at the sampling point (Figure 2) we collected water samples using new PET flasks (1L), using the vertical depth method (Carvalho, 1994). In the laboratory, the TSS was determined using the evaporation method (APHA, 1999). As required by Colby's method, the residue after evaporation was quantified in parts per million (ppm).

Channel width was determined by measuring the channel from bank to bank on the water surface at the water/sediment sampling point, using a tape.

After the determination of the sediment yield for each month, we calculated the average value of sediment yield for that period using the value of the current month and the value of the subsequent month. For example, to determine the average value for June, the values of June and July were used, and so on.

As the value was expressed in t.day ${ }^{-1}$, the average value was multiplied by the number of days of each month. For example, the average value obtained for April (average between $418.3 \mathrm{t} \mathrm{day}^{-1}$ and $406.9 \mathrm{t} \mathrm{day}^{-1}$, respectively for April and May) was
$412.6 \mathrm{t} \mathrm{day}^{-1}$. Multiplying $412.6 \mathrm{t} \mathrm{day}^{-1} \times 30$ days, the resulting value for April was 12,378.0 $\mathrm{t} \mathrm{month}^{-1}$ of sediment yielded from the Lavapés watershed. For computation of specific sediment yield we divided the annual sediment yield value by the catchment area (Haan et al., 1994).

The sediment delivery ratio (SDR), expressed as the percent of gross soil erosion by water that is delivered to a particular point in the drainage system (Da Ouyang, 1997), was estimated using two approaches: (1) the relief - length ratio technique (Equation 4 and Figure 3) (Carvalho, 1994; Haan et al., 1994); (2) the bifurcation ratio method (Equation 5) (Roehl, 1962; Carvalho, 1994; Haan et al., 1994).

Furthermore, a map showing the distance from the river network was elaborated using a GIS package and employing a 1:50,000 Digital Elevation Model of the study area.

$\mathrm{RC}=$ D.A. $/ \mathrm{C}$

Where: RC - Relief - channel length ratio (dimensionless) - to be plotted in Figure 3, D.A. - Difference of the elevations in the watershed divide and outlet $(\mathrm{m}), \mathrm{C}$ - Length of main river channel of the watershed $(\mathrm{m})$.

$\log \mathrm{DR}=4.50047-0.23043 \times \log 10 \mathrm{~W}-$

$0.51022 \times \log \mathrm{R}-2.78594 \times \log \mathrm{B}$

Where: DR - SDR (\%), W - watershed area $\left(\mathrm{km}^{2}\right), \mathrm{R}$ - relief - channel length ratio, $\mathrm{B}$ - bifurcation ratio (average value).

Considering that (1) measuring the electrical conductivity (EC) of the water is a suitable method to estimate the concentration of salts present (Ikeda et al., 1991) and to evaluate the degree of pollution, and (2) that the EC and concentration of total dissolved solids are in general closely associated (Das et al., 2006), on the same day with the hydrosedimentometrical samplings, EC was measured in situ using a previously calibrated Akso PCS35 EC meter.

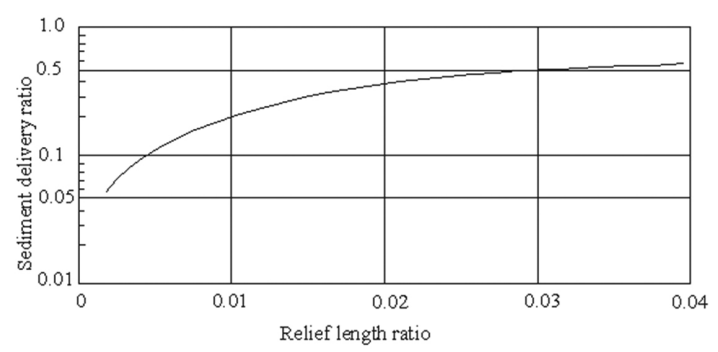

Figure 3. Relief-length ratio. Source: Haan et al. (1994). 


\section{Results and Discussion}

The annual sediment yield was 1,636.1 t. Not surprisingly, the total load was significantly smaller during the low water period than during the high water period (Silva and Schulz, 2007; Filizola and Guyot, 2009). December to January presented the greatest value, whereas June to July presented the lowest (Figure 4).

The specific sediment yield was $541.7 \mathrm{t} \cdot \mathrm{km}^{-2} \cdot \mathrm{y}^{-1}$. Such a value is greater than the $422 \mathrm{t} \cdot \mathrm{km}^{-2} \cdot \mathrm{y}^{-1}$ found by Machado and Vettorazzi (2003) in an Brazilian watershed $\left(59.7 \mathrm{~km}^{2}\right)$ located in Piracicaba $(100 \mathrm{~km}$ from Sorocaba) and it is close to values estimated by Haan et al. (1994) for various small watersheds scattered throughout the world.

The average monthly value for suspended load was $33.5 \mathrm{t}$, for bedload it was $102.9 \mathrm{t}$. Bedload was the predominant fraction of transported sediment throughout the period of study (Figure 5).

Owing to such results and others discussed below, we decided to carry out field work along the entire river network. In these trips neither expressive linear erosion features nor landslides were observed. These erosion features normally represent an important source of sediments (Nelson and Booth, 2002).

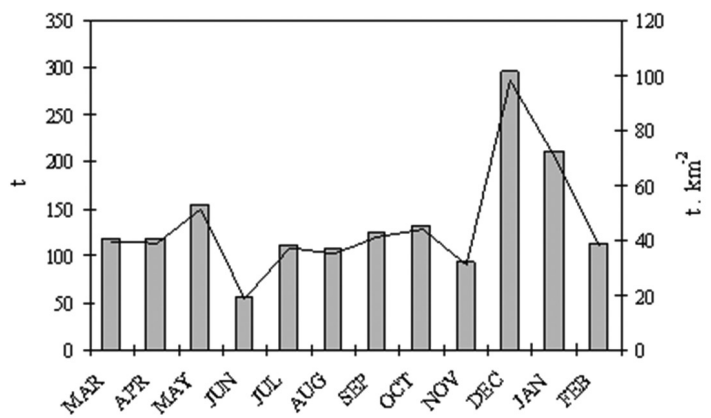

Figure 4. Monthly sediment yield (left axis - bars) and monthly specific sediment yield for study area.

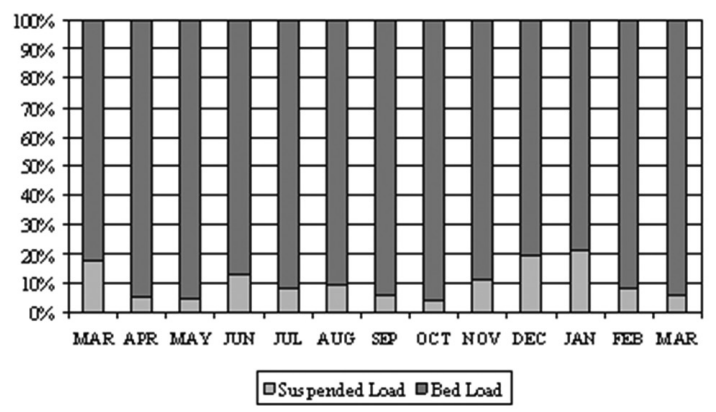

Figure 5. Proportions of suspended and bed loads for the study area.
Some unpaved streets, however, of which some were located close to river channels, were observed. Such features might be a possible source of sediment in medium to heavy rainfall events (sheetwash on road surfaces (Barton, 2002)), and indicate that sheet erosion seems to have much more influence on the sediment yield than linear erosion. In some catchments, sheet and rill erosion could dominate the sediment supply, whereas in others, channel erosion or gully erosion represents the primary source (Walling, 2005).

Some vacant lots were also observed in the study area (photo "C" of Figure 6). We observed construction wastes in some lots (photo "F" of Figure 6). Deforestation caused by urban expansion was not detected, but in dry months it is possible to observe some areas covered with burnt and sparse vegetation. There are many dwellings that practically reach the river channels, and are thus areas hydrologically threatened (photos "B", "E", Figure 6).

Increased coarse sediment supply does not raise chemical concerns, but can cause channel aggradations, resulting in reduced flow capacity that might lead to flooding or navigational problems and channel instability (Nelson and Booth, 2002; Allan, 2004). This is a typical scenario observed in the study area and perhaps the main concern raised by this study. Photo "E" of Figure 6 depicts a stretch of silted river.

Some parts of the river network have experienced enlargement of the channels and invasion by amphibian vegetal species, contributing to the siltation process (see photos of Figure 6). We observed that the factors affecting the enlargement of streams are: (1) streambank erosion occurring mainly in "U" shaped channel stretches due the nonexistence of forest riparian vegetation (photo "D" of Figure 6); (2) water pollution that stimulates an increase in amphibian macrophytes, favoring the siltation of some parts of the river network.

The scenario described does not occur uniformly along the entire catchment, in agreement with Booth (1990), who affirms that "whereas some channels expand gradually to accommodate a new, higher magnitude flow regime, other channels incise rapidly into their substrate, evacuating a proportionally much larger channel form whose capacity bear little relationship to the flows, either past or present, that have occurred".

We also observed that in many stretches the channels were straightened. The current drainage density $(\mathrm{Dd})$ value is $1.89 \mathrm{~km}$ of river. $\mathrm{km}^{-2}$. This value was certainly greater before urbanization (some decades ago), but due to the straightening 


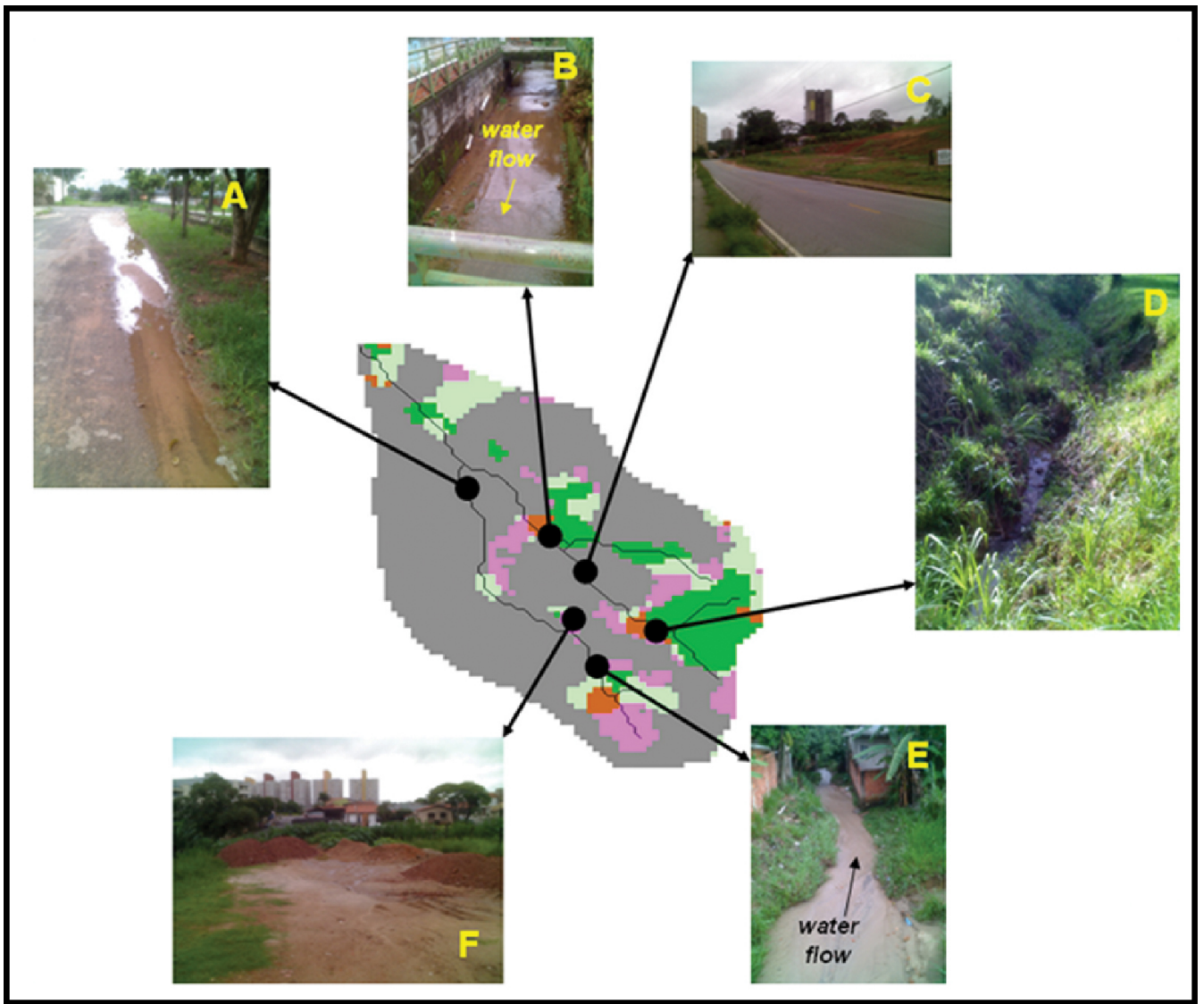

Figure 6. Set of photos taken in the study area.

process, the Dd value has diminished. This contributes to the increase in the flow in rainy periods, and this encourages the bedload of sediment at least in part of the watershed (Vanoni, 2006).

On many parts of the roads and also in many parts of river network (bed or banks) we observed coarse sand (photo "A", Figure 6) and fragments of tiles, bricks and other construction wastes that certainly are not materials autochthonous from the study area. In normal conditions, according to particle size, sediment tends to be deposited along a gradient down a river (Haan et al., 1994; Vanoni, 2006). But this does not occur in the study site, characterizing hydrosedimentological disequilibrium. The deposition of coarse - very coarse sediment downstream reduces roughness in the river bed and banks (Gregory, 2006).

The elevation range of the study area is $108 \mathrm{~m}$, and the length of the main river channel is $2,855 \mathrm{~m}$. Using these values in the relief-length relationship, a value of 0.037 was obtained. Plotting the resulting values in Figure 3, the SDR is estimated to be $60.0 \%$. Using Equation 5, the estimated value is $66.0 \%$. Taking into account the catchment area of the studied watershed and the SDR values, we consider that in the studied area the SDR is

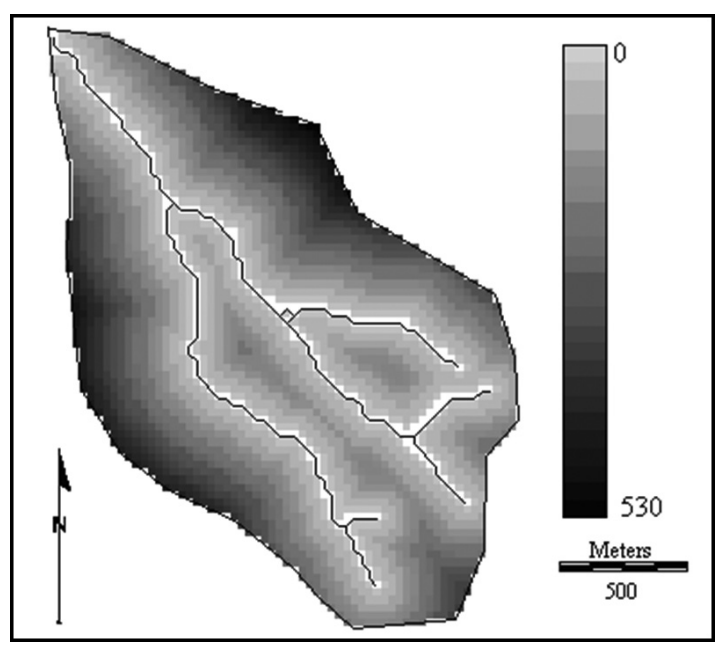

Figure 7. Distance (m) from river channels.

extremely high (Carvalho, 1994). We can see that the shape of the catchment area is not perfectly circular. Consequently, there are different distance gradients between upland points where soil particles may be detached and points in the river network where the sediment reaches the channel (Figure 7).

River discharge values did not present any significant correlation with the other parameters. 
On the other hand, a significant correlation value was noted between EC and TSS $\left(r^{2}=0.7\right.$, significant $=1 \%$ ), that presented seasonal similarity (Figure 8). The correlation value between the TSS and mineral fraction was 0.6 (significant $=5 \%$ ), whereas between TSS and organic fraction it was 0.7 (significant $=1 \%)$. The predominant fraction was mineral (average annual value $70 \%$ ). An exception was July, which presented an organic value of $73.4 \%$ (Figure 9).

The EC presented an average value of $300.1 \mu \mathrm{S} . \mathrm{cm}^{-1}$ and ranged from 89.8 to $408.0 \mu \mathrm{S} . \mathrm{cm}^{-1}$. On only two occasions were the values below $200 \mu \mathrm{S} . \mathrm{cm}^{-1}$. According to Figure 2, the study area has $69.5 \%$ of urbanized area. Comparatively, for a rural, small watershed located in São Carlos (220 km from study area), covered only with remnant vegetation patches and pasture, Primavesi et al. (2002) found values ranging from 6.1 to $25.6 \mu \mathrm{S} . \mathrm{cm}^{-1}$. Ometto et al. (2000) studying two small watersheds in the Piracicaba region, observed values for $\mathrm{EC}$ ranging from 55.5 to $81.6 \mu \mathrm{S} . \mathrm{cm}^{-1}$ for the Cabras watershed $(1.5 \%$ covered by urban settlements) and ranging from 81.6 to $272.8 \mu \mathrm{S} . \mathrm{cm}^{-1}$ for the Pisca watershed ( $10 \%$ covered by urban settlements). Ometto et al. (2000) stress that in such watersheds, domestic sewage is launched into the rivers and the impact of the urban areas is directly proportional to their size.

Photo " $\mathrm{B}$ " of Figure 5 confirms the situation for our study area, where we can see some domestic sewage pipes. Silva et al. (2009) found EC values ranging from 94 to $169 \mu \mathrm{S} . \mathrm{cm}^{-1}$ for the Sorocaba River (the river into the which Lavapes stream flows, Figure 10). These values were lower than the ones observed for Lavapes stream. Therefore, we believe that Lavapés is a considerable source of ions that flow into the Sorocaba River and, in the current state of conservation, the Lavapés stream contributes to deterioration of the water quality of the Sorocaba River.

Considering that gradients of anthropogenic land use are frequently superimposed on a gradient of physical environmental features, such as geological formation, soil type, topography, and others (Allan, 2004), we can summarize the anthropogenic driving forces that promote the hydrosedimentological imbalance of the region (Table 1). We created
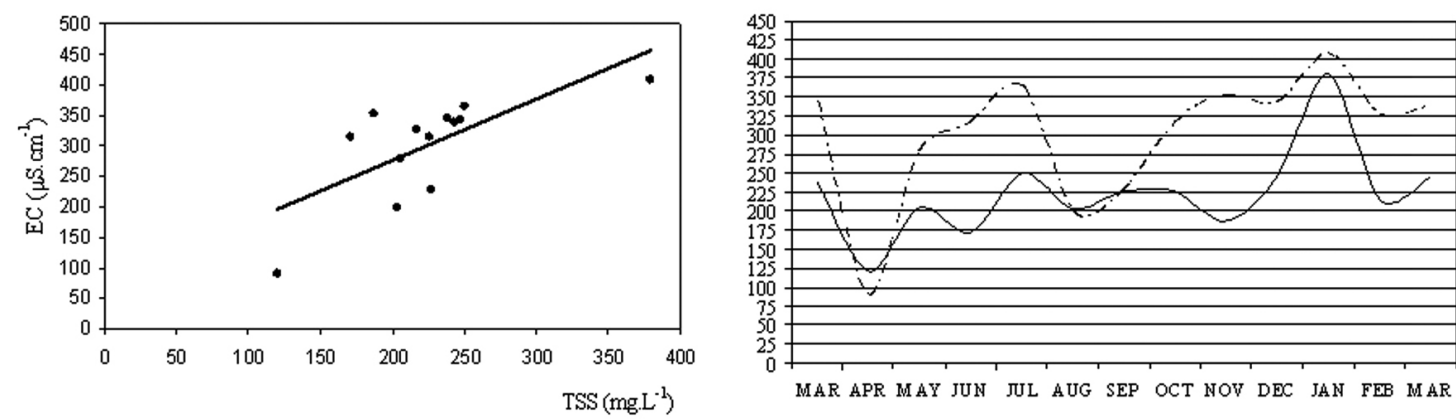

Figure 8. Left: Relationship between EC and TSS. Right: Seasonal variation of values of EC (dashed line - in $\mu$ S. $\mathrm{cm}^{-1}$ ) and TSS (full line, in mg. $\mathrm{L}^{-1}$ ).

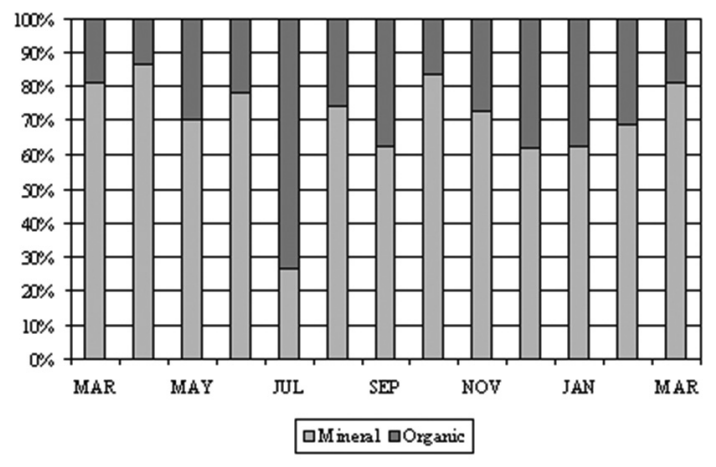

Figure 9. Percentage of mineral and organic content in TSS.

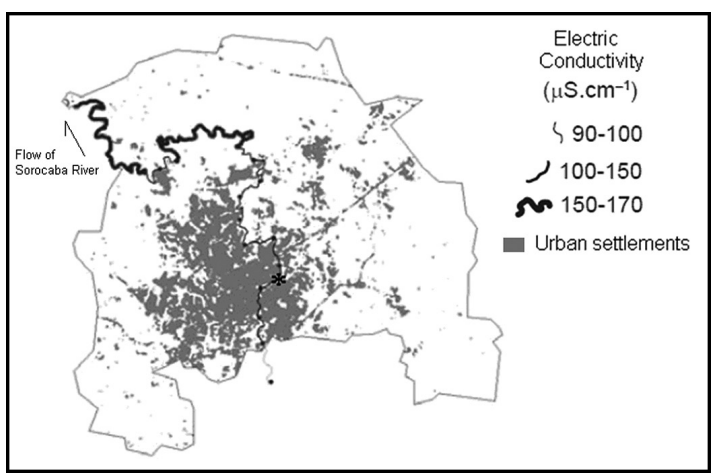

Figure 10. Representation of the changes in EC along the Sorocaba River. The confluence of the Lavapés Stream and the Sorocaba River is shown as indicated by an asterisk. Source of the map: Silva et al. (2009). 
Table 1. Summary of the main anthropogenic activities and their respective outcomes that promote the hydrosedimentological imbalance in the study area.

\begin{tabular}{ll}
\hline \multicolumn{1}{c}{ Anthropogenic activity } & \multicolumn{1}{c}{ Outcome } \\
\hline Riparian cleaning & Alters ecological dynamics of river network and encourages streambank erosion. \\
Construction waste dumping & $\begin{array}{l}\text { It is an important supply of allochthonous sediment that might reach the river } \\
\text { network, causing siltation in some stretches of the river network. }\end{array}$ \\
Sewage dumping & $\begin{array}{l}\text { Among many other threats, this expressively increases the water's electrical } \\
\text { conductivity. }\end{array}$ \\
\hline
\end{tabular}

Table 1 to emphasize the threats, and comment that if controlled, an expressive improvement in the local environmental quality of the study area might be achieved.

The rapidly expanding investigation of streams in the context of their catchments and landscapes clearly indicates that stream ecosystems are strongly affected by human actions across spatial scales (Allan, 2004). The studied area represents $0.7 \%$ of Sorocaba City. It is a small catchment, but influences many people who live in Sorocaba. Population size influences material importation, transformation and waste generation, but these aspects of urban metabolism are also dependent upon biophysical factors, urban forms and social factors (Kaye et al., 2006).

Historic conditions in many streams can greatly be modified as increasing urban runoff transforms intermittent and ephemeral drainages into perennial streams with elevated flood discharges. The urbanization-induced hydrological changes that have altered stream and riparian vegetation communities also probably affect the native wildlife species associated with them (White and Greer, 2006).

Similarly reported by such authors for a temperate catchment, the scenario certainly also occurs in other catchments of Sorocaba, but none have yet been studied and certainly there is no detailed knowledge sufficient for a solution to the related problems. This study suggests some actions and encourages futures studies in others parts of the city.

\section{Conclusions}

The annual sediment yield estimated for the period of the experiment was 1,636.1 t. The specific sediment yield was $541.7 \mathrm{t} \cdot \mathrm{km}^{-2} \cdot \mathrm{y}^{-1}$. Bedload is the predominant fraction and we conclude that it is an important threat to the study area, whose driving forces, which cause this problem, should be controlled. Geomorphic changes to stream channel morphology were observed and clearly have been influencing the hydrosedimentological dynamic of the study area.

We affirm that the increase in urbanization of the study area has resulted in a hydrosedimentological disequilibrium caused by the inexistence of riparian vegetation, the dumping of construction wastes, and the inadequate disposal of sewage. We stress that if the main degrading factors were controlled, an expressive improvement of the environmental quality might be achieved. The main activities should focus on inspection to avoid (or eliminate) degrading activities and for reconstruction of natural or semi-natural environments in severely damaged areas.

\section{Acknowledgements}

We are grateful to the Brazilian agencies FAPESP and FUNDUNESP for financial support.

\section{References}

ALLAN, JD. 2004. Landscapes and Riverscapes: the influence of land use on stream ecosystems. Annual Review of Ecology, Evolution and Systematics, vol. 35, p. 257-284. http://dx.doi.org/10.1146/annurev. ecolsys.35.120202.110122

American Public Health Association - APHA. 1999. Standard Methods for the Examination of Water and Wastewater. 20th ed. Washington: APHA. 1325 p.

ARAUJO, SCS., SALLES, P. and SAITO, CH. 2008. A case study on qualitative model evaluation using data about river water quality. Ecological Informatics, vol. 3, p. 13-25. http://dx.doi.org/10.1016/j. ecoinf.2007.09.004

BARTON, CM. 2002. A sediment budget for the Pipers Creek Watershed: applications for urban stream restoration. University of Washington. 143 p. [MSc Thesis Civil and Environmental Engineering]. Available from: <http://water.washington.edu/ Theses/Barton\%20thesis.pdf>.

BOOTH, DB. 1990. Stream-channel incision following drainage-basin urbanization. Water Resources Bulletin, vol. 26, p. 407-417. http://dx.doi. org/10.1111/j.1752-1688.1990.tb01380.x 
CARVALHO, NO. 1994. Hidrossedimentologia Prática. Rio de Janeiro: CPRM-Companhia de Pesquisa em Recursos Minerais. 372 p.

CHIN, A. 2006. Urban transformation of river landscapes in a global context. Geomorphology, vol. 79, p. 460-487. http://dx.doi.org/10.1016/j. geomorph.2006.06.033

DA OUYANG, B. 1997. Predicting sediment delivery ratio in Saginaw Bay Watershed. In Proceedings of 22nd National Association of Environmental Professionals Conference; 1997. Orlando. p. 659-671. Available from: <http://www.iwr.msu.edu/ - ouyangda/sdr/ sag-sdr.htm>.

DAS, R., SAMAL, NR., ROY, PK. and MITRA, D. 2006. Role of electrical conductivity as an indicator of pollution in shallow lakes. Asian Journal of Water, Environment and Pollution, vol. 3, p. 143-146.

Environmental Protection Agency - EPA. 2009. Environmental impact and benefits assessment for final effluent guidelines and standards for the construction and development category. Washington. 374 p. Available from: <http://water.epa.gov/scitech/ wastetech/guide/construction/upload/2008_12_8_ guide_construction_files_environment.pdf $>$.

FILIZOLA, N. and GUYOT, JL. 2009. Suspended sediment yields in the Amazon basin: an assessment using the Brazilian national data set. Hydroligical Processes, vol. 23, p. 3207-3215. http://dx.doi. org/10.1002/hyp.7394

GERGEL, SE., TURNER, MG., MILLER, JR., MELACK, JM. and STANLEY, EH. 2002. Landscape indicators to human impacts to riverine systems. Aquatic Sciences, vol. 64, p. 118-128. http:// dx.doi.org/10.1007/s00027-002-8060-2

GREGORY, KJ. 2006. The human role in changing river channels. Geomorphology, vol. 79, p. 172-191. http://dx.doi.org/10.1016/j.geomorph.2006.06.018

HAAN, CT., BARFIELD, BJ. and HAYES, JC. 1994. Design Hydrology and Sedimentology for Small Catchments. Oxford: Academic Press.

GROPPO, JD., MORAES, JM., BEDUSHI, CA., GENOVEZ, AM. and MARTINELLI, LA. 2008. Trend analysis of water quality in some rivers with different degrees of development within the São Paulo State, Brazil. River Research and Applications, vol. 24, p. 1056-1067. http://dx.doi.org/10.1002/rra.1091

IKEDA, S., MOTONAKA, J., KOIZUMI, T. and ISHIKAWA, T. 1991. Ion concentrations in river water and their estimation from electric conductivity. Analytical Sciences, vol. 7, p. 1077-1080. Supplement. http://dx.doi.org/10.2116/analsci.7.Supple_1077

KAYE, JP., GROFFMAN, PM., GRIMM, NB., BAKER, LA. and POYAT, RV. 2006. A distinct urban biogeochemistry? Trends in Ecology and Evolution, vol. 21, p. 192-199. PMid:16701085. http://dx.doi. org/10.1016/j.tree.2005.12.006
MACHADO, RE. and VETTORAZZI, CA. 2003. Simulação da produção de sedimentos para a microbacia hidrográfica do ribeirão dos Marins (SP). Revista Brasileira de Ciência do Solo, vol. 27, p. 735-741. http://dx.doi.org/10.1590/S010006832003000400018

MARTIN, RH. 2011. Critical thresholds for sediment mobility in an urban stream. Georgia State University. 47 p. [Geosciences thesis].

NELSON, EJ. and BOOTH, DB. 2002. Sediment sources in an urbanizing, mixed land-use watershed. Journal of Hydrology, vol. 264, p. 51-68. http://dx.doi. org/10.1016/S0022-1694(02)00059-8

OLIVEIRA, JB., CAMARGO, MN., ROSSI, M. and CALDERANO FILHO, B. 1999. Mapa Pedológico do Estado de São Paulo. Legenda Expandida. Campinas: Instituto Agronômico; Rio de Janeiro: Embrapa-Solos. 64 p.

OMETTO, JPHB., MARTINELLI, LA., BALLESTER, MV., GESSNER, A., KRUSCHE, AV., VICTORIA, RL. and WILLIAMS, M. 2000. Effects of land use on water chemistry and macroinvertebrates in two streams of the Piracicaba river basin, southeast Brazil. Freshwater Biology, vol. 44, p. 327-337. http://dx.doi. org/10.1046/j.1365-2427.2000.00557.x

OOSHAKSARAIE, L., BASRI, NEA., BAKAR, AA. and MAULUD, KNA. 2009. Erosion and sediment control to minimize impacts of housing construction activities on water resources in Malaysia. European Journal of Scientific Research, vol. 33, p. 461-470.

PAUL, MJ. and MEYER, JL. 2001. Streams in the urban landscape. Annual review of Ecology, Evolution and Systematics, vol. 32, p. 333-365. http://dx.doi. org/10.1146/annurev.ecolsys.32.081501.114040

POLETO, C., BORTOLUZZI, EC., CHARLESWORTH, SM. and MERTEN, GH. 2009. Urban sediment particle size and pollutants in Southern Brazil. Journal of Soil and Sediments, vol. 9, p. 317-327. http://dx.doi. org/10.1007/s11368-009-0102-0

PORTO, P., WALLING, DE. and CALLEGARI, G. 2009. Investigating the effects of afforestation on soil erosion and sediment mobilization in two small catchments in Southern Italy. Catena, vol. 79, p. 181-188. http://dx.doi.org/10.1016/j. catena.2009.01.007

PRIMAVESI, O., FREITAS, AR., PRIMAVESI, AC. and OLIVEIRA, HT. 2002. Water quality of the Canchim's creek watershed in São Carlos-SP, Brazil, occupied by beef and dairy cattle activities. Brazilian Archives of Biology and Technology, vol. 45, p. 209-217. http://dx.doi.org/10.1590/S151689132002000200013

ROEHL, JW. 1962. Sediment source areas, delivery ratios and influencing morphological factors. In Symposium on Land Erosion; 1962. International Association of 
Hydrological Science. p. 202-213. Available from: <http://iahs.info/redbooks/a059/059023.pdf>.

SCAPIN, J., PAIVA, JBD. and BELING, FA. 2007. Avaliação de métodos de cálculo do transporte de sedimentos em um pequeno rio urbano. Revista Brasileira de Recursos Hidricos, vol. 12, p. 5-21.

SILVA, AM. 2007. Potencial natural de erosão no município de Sorocaba, São Paulo, Brasil. Revista Internacional de Desastres Naturales, Accidentes y Infraestructura Civil, vol. 8, p. 1-10.

SILVA, AM. and SCHULZ, HE. 2007. Hydrossedimentological dynamic on Água Fria Watershed. Brazilian Archives of Biology and Technology, vol. 50, p. 861-870. http://dx.doi. org/10.1590/S1516-89132007000500014

SILVA, AM., ROSA, AH., ANTUNES, FM., NOGUEIRA, DP. and LESSA, SS. 2009. Relationship between water quality and land use along a stretch of the Sorocaba River (SP). Journal of the Brazilian Society of Ecotoxicology, vol. 4, p. 65-71. http://dx.doi. org/10.5132/jbse.2009.01.009

SILVA, AM., URBAN, RC. and MANFRÉ, LA. 2011. Landscape indicators of human impacts to riverine systems-a study case of a Brazilian urbanized watershed. In Annals of 8 th World Congress of the International Association of Landscape Ecology; 2011. Beijing.

SOUZA, O., OLIVEIRA, AMS. and QUEIROZ, W. 2009. Produção de sedimentos na região metropolitana de SP-o caso da microbacia do córrego
Pau d'alho. Revista Brasileira de Geomorfologia, vol. 10, p. 63-72.

TAYLOR, KG. and OWENS, PN. 2009. Sediments in urban river basins: a review of sediment-contaminant dynamics in an environmental system conditioned by human activities. Journal of Soils and Sediments, vol. 9, p. 281-303. http://dx.doi.org/10.1007/ s11368-009-0103-z

URBAN, RC. 2011. Fragilidade Ambiental, qualidade do solo e da água em uma microbacia de ocupação urbana, Sorocaba/SP. Sorocaba: Universidade Estadual Paulista. 50 p. [MSc Dissertation Civil and Environmental Engineering].

United State Department of Interior - USDI. 2001. Water measurement manual. Washington. 317 p. Available from: <http://www.usbr.gov/pmts/hydraulics_lab/ pubs/manuals/WMM_3rd_2001.pdf>.

VANONI, VA. 2006. Sedimentation Engineering. Reston: ASCE. 424 p.

WALLING, DE. 2005. Tracing suspended sediment sources in catchments and river systems. Science of the Total Environment, vol. 344, p. 159-184. PMid:15907516. http://dx.doi.org/10.1016/j. scitotenv.2005.02.011

WHITE, MD. and GREER, KA. 2006. The effects of watershed urbanization on stream hydrology and riparian vegetation of Los Peńasquitos Creek, California. Landscape and Urban Planning, vol. 74, p. 125-138. http://dx.doi.org/10.1016/j. landurbplan.2004.11.015 